\title{
The Influence Of Organizational Culture, Organizational Structure And Work Environment Over Lectures Behavior At Trisakti Tourism Collage
}

\author{
Safrodin ${ }^{1}$, Thamrin Abdullah ${ }^{2}$, Muchlis R. Luddin ${ }^{3}$ \\ \{safrodinunj@gmail.com ${ }^{1}$, thamrinabdullah@unj.ac.id ${ }^{2}$, muchlisrluddin@unj.ac.id ${ }^{3}$ \} \\ Universitas Negeri Jakarta, Indonesia ${ }^{13}$ \\ Muhammadiyah Prof. Dr. Hamka University, Indonesia ${ }^{2}$
}

\begin{abstract}
Ethical Behavior involves the study of moral issues and choices. It is related to the proper categorization of right and wrong preferences. This study analyzes the Influence of organizational culture, structure, and work environment over the ethical behavior of lecturers at Trisakti tourism collage of Jakarta. A survery sample was used with a sample population of 70 employers. Data was obtained by spreading valid instrument and documentation. The data obtained were analyzed using a software Statistical Program for Social Sciences (SPSS) for Windows. The research result shows that work environment, organizational culture and structure, directly drives positive influence over ethical behavior. Therefore to enhance the ethical behavior of an employer, these features should be improved and taken into serious consideration.
\end{abstract}

Keywords: organizational culture, organizational structure, work environment, ethical behavior, Lecturer behavior.

\section{Introduction}

Generally, ethical behavior, work environment, organizational culture and structure, as well as individual actions contribute to the success or failure of an industry. In dealing with this, three kinds of social ethical behaviors among lecturers at Trisakti tourism collage were identified. These are Social ethics between lecturers and students, one lecturer and another lecturer, and between lecturers and leaders. This assessment was previously conducted by the consultancy agency for the development of human resources for lecturers in higher institutions as a material for decision making on people's behavior.

Kreitner, 2007 argues that ethics involves the study of moral issues and choices. It is related to right or wrong, good or bad, grayed-out problems that can be grouped into the black or white category. Its moral implications could lead to the success or failure of an organization. Meanwhile [1] "ethics refers to the study of moral principles or values that determines if the right or wrong actions are good or bad."

Ethical behaviors derived from moral principles, are used to make decisions which can be likened to fundamental values. There are three ethical principles associated with these values namely, (1), utilitarianism; which suggests that we always look for the best among the good from a large number of people. In other words, we must always opt for the highest levels of satisfaction for those affected. (2), Individual Truth; reflects on the belief that everyone has the right to act independently. Such as freedom of movement, physical security, speech, and justice. (3), distributive justice; indicate that people with similar work have to receive same benefits, while those with contrasting jobs should receive disparate benefits. The term ethic comes from an ancient Greek word, "ethos" which has numerous meanings. Ethos could be refered to several things such asordinary residence, pastures, cages, customs, morals, 
temperaments, feelings of attitudes and ways of thinking. Its prural form "ta etha" means custom. This latter meaning is the background used in the formation of an ethical term which the Greek philosopher Aristotle (384-322 BC) used to demonstrate moral philosophy [2].

Work environment basically is the existence of both sufficient facilities and social aspects used to encourage lecturers in carrying out their duties. For lecturers to effectively and efficiently carry out their tasks, a work environment capable of supporting their togetherness is required. The work environment should be created with respect to its goals. In other words, it needs to potentially support group cohesiveness in carrying out tasks that ultimately improves the performance of an organization.

According to Rahmawanti, Nela Pima, Bambang Swasto, 2014, the work environment nfluences and encourages workers to execute their tasks.

Furthermore, [3] reveals that work environment is a collection of forces surrounding an organization that has an impact on the way it is operated and accessed. It comprises of skilled raw materials, personnel, as well as any information needed to enhance technology and decision making. The work environment is directly considered either physically or socially with regards to individual decision making within the organization.

There are two kinds of work environment, the general environment and specific environment. The former includes economic conditions, educational, political, legal, and cultural values. While the latter is related to the position of the organization in an effort to develop its network.

Sedarmayanti, 2008 defines the physical environment as the direct or indirect circumstances surrounding employee in a workplace.

Organizational structure refers to the formal configurations between individual and groups with respect to the allocation of tasks, responsiblilities, and authority (Greenberg, 2008). It is also defined as a relationship of various groups whose functions are described in an organizational chart. The chart shows the division of tasks, and responsibilities of each individual.

According to Colquitt, Jason A. Jeffery A. Le Pine, 2008, organizational structure formally dictates how jobs and tasks are divided and coordinated between individuals and groups within the company. In addition, it explains the job functions of every job in an organization and relationship between those jobs.

Steven L.McShane, 2008, describes organizational structure as the division of labor, and the pattern of coordination, communication, workflow, and formal power that directs an organizational activity. Acording to Stephen P Robbins, 2016, "an organizational structure determines how tasks are divided, grouped, and formally coordinated." James A.F. Stoner, R. Edward Freeman, and Daniel R. Gilbert, 2016, defines an organizational structure as a framework thought by managers to divide and coordinate the activities of members of an industry.

Osibanjo Omotayo Adewal, 2013, beamed that organizational culture affects corporate performance, a deeply embedded form of social control that influences employee decisions and behavior. Furthermore, Andrew J. Dubrin and R. Duane Ireland, 2013, opined that organizational culture is a system that is part of the values and beliefs that influences employee behavior. The life of employees in an organization will influence organizational characteristics which will, in turn, influence the organizational culture in the firm. 


\section{Research Methods}

This research made use of a quantitative research approach with path analysis technique. It describes the current condition and answers the question on the characteristics, correlation and influence of the variables. While, the survey is used to disclose the incident, distribution and interrelationship of each variable. Path analysis is used to analyze the relationships between the direct and indirect effects of independent variables (exogenous) over the dependent variable (endogenous) which is preceded by normality test, estimated error and regression analysis, and terminated with the Goodness Fit Index (GFI) test using the Lisrel program.

The variables referred to in this study are the ethical behavior $\left(\mathrm{X}_{4}\right)$, work environment $\left(\mathrm{X}_{3}\right)$, organizational structure $\left(\mathrm{X}_{2}\right)$, organizational culture $\left(\mathrm{X}_{1}\right)$.

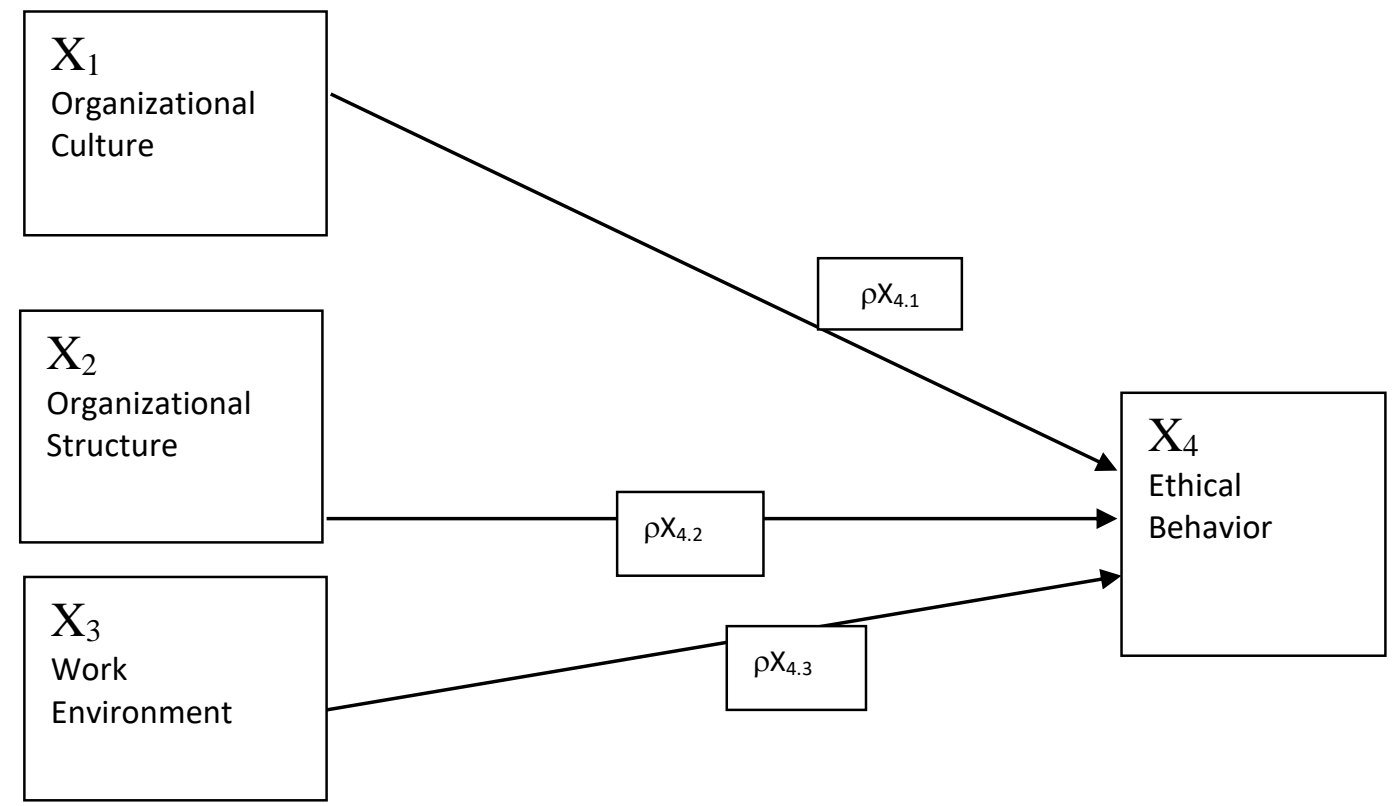

Fig.1. Research Constellation

\section{Results and Discussion}

Data descriptions are the ethical behavior instruments (X4), organizational culture instruments (X1), organizational structure instruments (X2), and work environment instruments (X3). The description of every variable is presented in a series such below. 


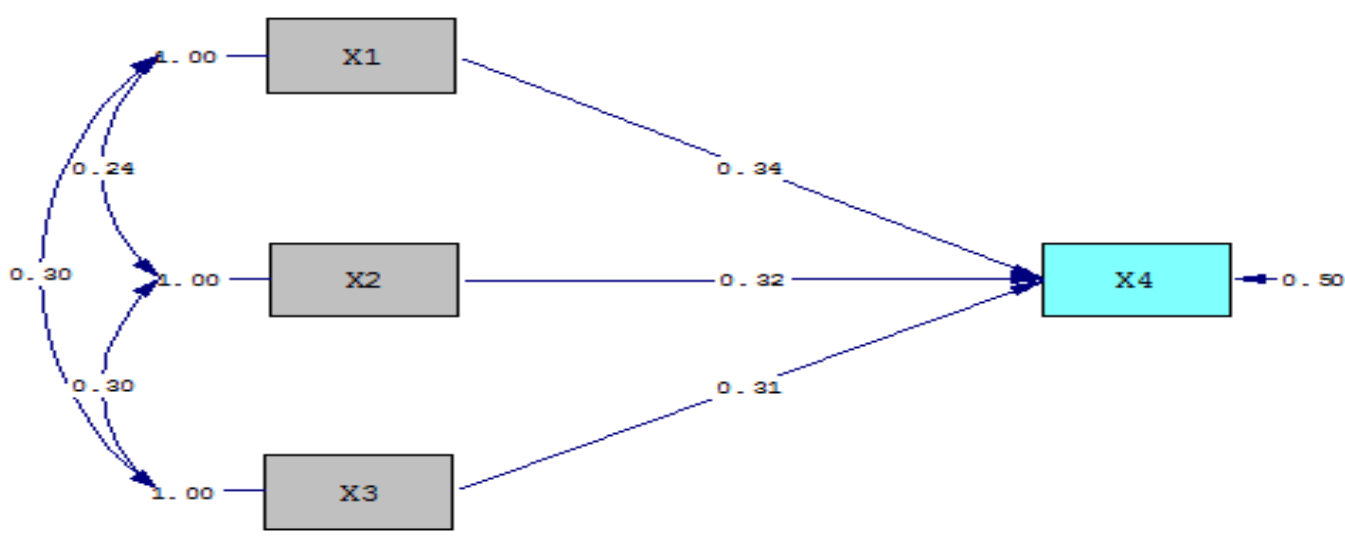

Chi-Square=0.00, df=0, P-value=1.00000, RMSEA=0.000

Fig.2. Structural Model Based on Calculation Results Lisrel

The picture above is tested for Goodness Fit Index (GFI) with the help of the Lisrel program whose results can be seen in the chart below.

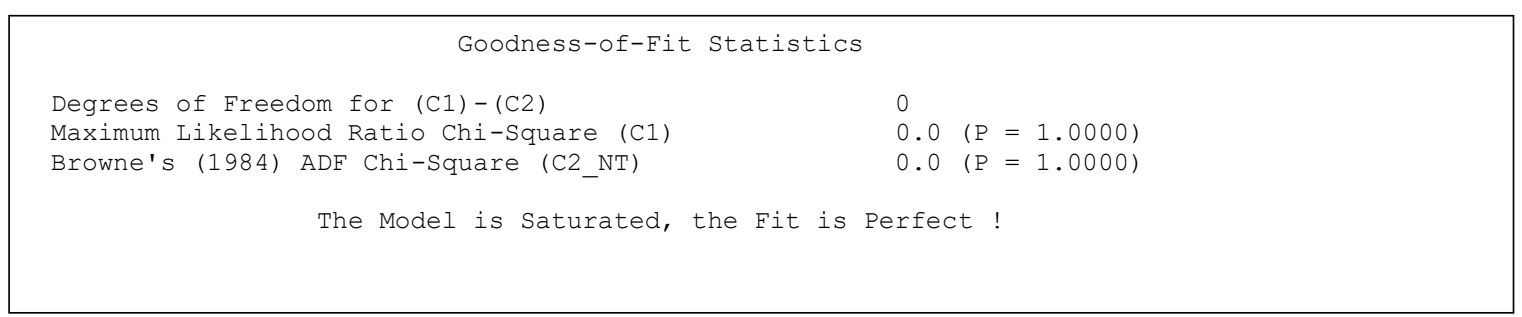

Fig.3. Goodness Fit Index (GFI) Test Results

Table 1. Direct Effects Between Variables

\begin{tabular}{|c|c|c|c|c|c|}
\hline \multirow{2}{*}{ No. } & \multirow{2}{*}{ Direct Influence } & \multirow{2}{*}{ Path coefficient } & \multirow{2}{*}{ dk } & \multirow{2}{*}{ tcount } & $\mathbf{t}_{\text {table }}$ \\
\hline & & & & & $\alpha=\mathbf{0 , 0 5}$ \\
\hline 1. & $\mathrm{X}_{1}$ to $\mathrm{X}_{4}$ & 0,336 & 66 & $3,64 * *$ & 2,00 \\
\hline 2. & $\mathrm{X}_{2}$ to $\mathrm{X}_{4}$ & 0,324 & 66 & $3,51 * *$ & 2,00 \\
\hline 3. & $X_{3}$ to $X_{4}$ & 0,313 & 66 & $3,33 * *$ & 2,00 \\
\hline
\end{tabular}

** = very significant $\left(\mathrm{t}_{\text {count }}>\mathrm{t}_{\text {table }}\right)$ 
Chi-Square price $=0.0$, free degree $=0, \mathrm{p}$ value $=1.0000>0.05$ or not significant, so that the fit model is classified as very good.

The calculation of path analysis revealed the data on the direct influence of organizational culture $\left(\mathrm{X}_{1}\right)$ over ethical behavior $\left(\mathrm{X}_{4}\right)$ signed by correlation, and path coefficient score of 0.510 and 0.336 respectively. It means that organizational culture $\left(\mathrm{X}_{1}\right)$ directly has a positive influence over the ethical behavior $\left(\mathrm{X}_{4}\right)$. Its influence over ethical behavior was greater than both the organizational structure and work environment. It shows that variations of ethical behavior among the lecturers have been influenced by the organizational culture, thereby, leading to in ethical changes variations.

The direct influence of organizational structure $\left(\mathrm{X}_{2}\right)$ over ethical behavior $\left(\mathrm{X}_{4}\right)$ signed by the correlation, and path coefficient scores of 0.501 and 0.324 respectively, means that organizational structure $\left(\mathrm{X}_{2}\right)$ directly has a positive influence over ethical behavior $\left(\mathrm{X}_{4}\right)$. The organizational structure influences a person in taking actions, therefore, if the organizational structure is not properly run, the ethical behavior could result to an ufriendly effect andvice versa. In this case, the ethical behavior among the lecturers at the Trisakti tourism collage Jakarta have been influenced by the organizational structure.

\section{Conclusion}

Based on the overall statements, it can be concluded that there is a positive direct influence of: organizational culture over ethical behavior, organizational structure on the ethics of action and direct influence on the working environment on the ethics of acting.

\section{References:}

[1] Kreitner, Robert And Angelo.:Organizational Behavior. New York: McGraw Hill (2007)

[2] McShane, Steven L. and Marry Ann Von Glinow.: Organizational Behavior. New York: McGraw Hill (2008)

[3] Kees Bertens.: Etika, Jakarta: Gramedia (2007)

[4] Rahmawanti, Nela Pima, Bambang Swasto, dan Arik Prasetya.: Pengaruh Lingkungan Kerja Terhadap Kinerja Karyawan: Studi pada Karyawan Kantor Pelayanan Pajak Pratama Malang Utara, (Jurnal Administrasi Bisnis, Vol. 8 No. 2, Maret 2014), h.1-9.

[5] Jones, Gareth R.: Organizational Theory: Design and Change. New Jersey: Printice hall pub, (2004)

[6] Sedarmayanti.: Organisasi Kepemimpinan dan Perilaku Administrasi. Jakarta: PTGA, 2008.

[7] Greenberg, Jerald and Robert A. Baron.: Behavior in organization, $9^{\text {th }}$ edition. New Jersey: Prentice Hall (2008)

[8] Colquitt, Jason A. Jeffery A. Le Pine, and Michael J. Wesson.: Organizational Behavior: Improving Performance and Commitment in the Workplace. New York: McGraw Hill, 2008.

[9] McShane, Steven L. and Mary Ann Von Glinow.: Organizational Behavior, New York: McGraw-Hill (2008)

[10] Robbins, Stephen P., Perilaku Organisasi.: Konsep, Kontroversi dan Aplikasi, Jakarta: Prenhallindo (2016)

[11] James A.F. Stoner, R. Edward Freeman, and Daniel R. Gilbert, Jr.: Manajemen, terjemahan Alexander Sindoro (Jakarta: Gramedia, 2016), h.7.

[12] Osibanjo Omotayo Adewal.: Impact of Organizational Culture on Human Resource Practices: A Study of Selected Nigerian Private Universities, (Journal of Competitiveness, Vol. 5, Issue 4, December 2013, ISSN 1804-171X, hh.115-133. 
[13] Andrew J. Dubrin and R. Duane Ireland.: Management and Organization (Ohio: South Western Pub., 2013), hh.571-572. 